\title{
Linnebjer-A South Swedish Oak Forest and Meadow Area-Revisited after Half a Century
}

\author{
Folke 0. Andersson' ${ }^{1}$, Bengt Nihlgård ${ }^{2}$ \\ ${ }^{1}$ Department of Ecology, Swedish University of Agricultural Sciences, Uppsala, Sweden \\ ${ }^{2}$ Department of Biology, Lund University, Lund, Sweden \\ Email: folke.andersson@slu.se, bengt.nihlgard@biol.lu.se
}

Received 17 December 2015; accepted 22 January 2016; published 25 January 2016

Copyright (C) 2016 by authors and Scientific Research Publishing Inc.

This work is licensed under the Creative Commons Attribution International License (CC BY). http://creativecommons.org/licenses/by/4.0/

cC) (i) Open Access

\section{Abstract}

An oak forest and three wet meadows/fens were reinvestigated after 50 years concerning tree vitality, biomass and productivity, and soil chemistry. Sulphur and nitrogen deposition has changed dramatically during these years, and the aim was to analyse the differences in both the oak forest and the open field ecosystems. Trees were re-measured and soil profiles were resampled. Important visible changes in the oak forest were stated concerning the vitality of oaks. Aboveground there was a decrease in tree biomass, production and litter fall, but a huge increase in standing dead logs. During the years, the deposition of sulphur had decreased drastically, but nitrogen deposition was still high. Soil acidification in the forest had decreased, reflected in an increased base saturation in the forest, in spite of slightly lowered pH-values. Strongly increased amounts of exchangeable $\mathrm{Ca}$ and $\mathrm{Mg}$ now appeared in the forest soil, and a substantial transport of calcium and magnesium had obviously taken place from the forest soil to the meadow and fens during the years. However, the most important soil change was the accumulation of organic matter. The increased accumulation of organic matter in turn meant increased amounts of colloid particles and microsites for ion exchange in the soil. This favoured 2-valence base cations, and especially Ca and Mg that increased very much in all the studied ecosystems. Carbon as well as nitrogen had strongly increased in the forest, meadow and fen soils. This was interpreted as a natural result of increased vegetation growth due to high nitrogen deposition, increased global annual temperature and increased carbon dioxide concentration in air. It was concluded that the decreased deposition of sulphur had had a positive effect on soil chemistry, and that the deposition of nitrogen probably had stimulated vegetation growth in general, and contributed to increased amount of organic matter in the soils. However, in this studied oak forest, the decreased vitality and many killed trees were also suspected to be a result of high nitrogen deposition. Obviously increased tree growth was counteracted by decreased stress resistance, and increased appearance of pathogens in the oak trees. 


\section{Keywords}

\section{Oak Disease, Tree Vitality, Deposition of S and N, Soil Acidification, Soil C and N Accumulation, Increased Amounts of $\mathrm{Ca}$ and $\mathrm{Mg}$}

\section{Introduction}

The area Linnebjer was subject to an investigation of soil and vegetation already at the end of the 1950s. It was intensively followed until the 1970s. The results were synthesised in a doctoral thesis [1] and published in two main papers [2] [3]. An additional paper was published later [4]. Thanks to the thorough documentation, it was possible to return to the area during the 2010s to consider possible changes and their causes in a time perspective of more than half a century. This was considered of special interest due to the important changes in deposition of sulphur and nitrogen during this period.

\section{Early Major Findings}

As a background to the present paper the major results of the first investigations will be summarised. Linnebjer is a nature reserve seven km ENE of Lund, S Sweden of 38 ha, dominated by a pedunculate oak, lime and hazel forest intermingled with small, moist areas, mostly with meadow and fen vegetation. The forest should be seen as remnants of a forest, which earlier was subject to a different utilisation and management than today. The bedrock consists of Silurian slate covered by a shallow layer of clay mixed with rests from the calcareous bedrock area a few km further south. A Special area of $130 \times 140 \mathrm{~m}$ was intensively investigated in the northern part. Plants, vegetation, soil water conditions as well as soil chemical and physical properties were mapped and classified [2].

The identified ecosystems appear in a gradient from dry, or more properly moderately fresh, to wet conditions. The soil and terrain regulate the governing factor, the ground water, in a way that the forest has a good aeration, while the meadow and fen ecosystems have less good oxygen conditions. In the forest there is a dominating vertical water movement, while in the meadow ecosystems mainly a lateral water movement prevails. The forest is dominated by an Oxalis acetosella-ecosystem. The meadows are dominated by a Filipendula ulmaria-ecosystem and more fen-like ecosystems with Carex caespitosa and Carex flacca, respectively.

The discussed vertical and horizontal water movements result in forest soils with rather acid mull, and meadows/fens with humus types of more or less neutral reaction. A gradient of humus types from mull to fen-mull and anmoor were found. The humus types have different chemical properties as a result of the mediating effects of the water factor. The most expressive evidence of this circumstance is seen in the distribution of $\mathrm{pH}$ and the percentage of exchangeable metallic cations. A number of other soil chemical factors vary along these gradients, e.g. nitrogen mineralisation, turnover of phosphorus and potassium.

\section{History of the Present Reservation}

As stated above the Linnebjer forest is a nature reserve and a remnant of an earlier large forest-the "Skrylle forest”. Today one can locally find small patches of this forest still remaining in the area. Linnebjer is such an example. The development of these forests depended on Man's use of the forests-in other words the impact of Man was and still is important for their development.

The historical development and the use of the present Linnebjer reservation is discussed by [2]. The oldest influence of Man dates back to Mesolithic time, about 6000 years BC. Then hazel forest was dominating [5]. Beech forest became much later more common. As the human population increased the pressure on land became harder. It is assumed that forests became more open through grazing and cultivation, and small patches left in the landscape became gradually rare. Still the forests were used as a source for building and fire material. The present day's forests should be seen as relict forests.

In later time the Linnebjer forest become dominated by oak, linden and hazel. Oaks had a timber value, often belonging to the State. Linden produced long and slender poles for roof building. Hazel was used as reinforcing rods in building "clay houses", typical for the landscape. The vegetation is described in [2] [3]. See also [4]. The 
management at that time led to a "clean” forest with an overstory of straight oak stems, coppiced straight lindens and suppressed hazel. A new management plan was accepted in 1980. The maintenance had earlier been sporadic, but from now on regular management of meadows and forests was the case. The meadow in the Special area was made more open. Some oaks were taken away favouring the meadows and the paths, as the forest has several visitors, particularly in springtime.

Originally the Linnebjer forest was owned by the State-The Swedish Forest Service. It was early set aside as a nature reserve due to its characteristics. In 1980 the area was bought by the National Trust of Sweden administrated by the Swedish Nature Conservancy Board. Simultaneously the Local County Board became responsible for the maintenance. Today the Linnebjer nature reserve is enlarged and includes also areas north of the reserve with open fields and a magnificent view of an open landscape. It is designated as an area belonging to Natura 2000 in order to promote habitats for plants and animals (Figure 1).

Linnebjer has a preservation plan dated 2005-12-16 (Plan for maintenance 2005-In Swedish: Bevarandeplan, Linnebjer). From now on there is a national interest connected to the area as to vegetation and species. The dominating area is covered by a Quercus robur, Tilia cordata and Corylus avellana forest (22.5 ha), Fagus sylvatica forest (1.4 and 0.1 ha, rich in herbs and Luzula pilosa, respectively), a meadow with tall herbs (0.9 ha) and dry-fresh species representing rich lowland grassland of Fennoscandia type (4.3 ha). The latter is situated north of the Special area (Figure 1). The following species in particular are protected: Geranium palustre (ENendangered), Cares hartmanii (VU-vulnerable) and Dactylorchis majalis (NT—not favoured). These species are redlisted as well as the following birds: Columba oenas, Dendrocarpus minor and Parus palustris (all NT).

Half a century is a long time. Some changes have been observed with the naked eye and not documented, others have been documented. Recent observations indicate that there is in general a dynamics in vegetation, which is greater than before. Today there are more wind throws, more dying or dead trees as well as a more intensive management of the meadows, especially in the Special area.

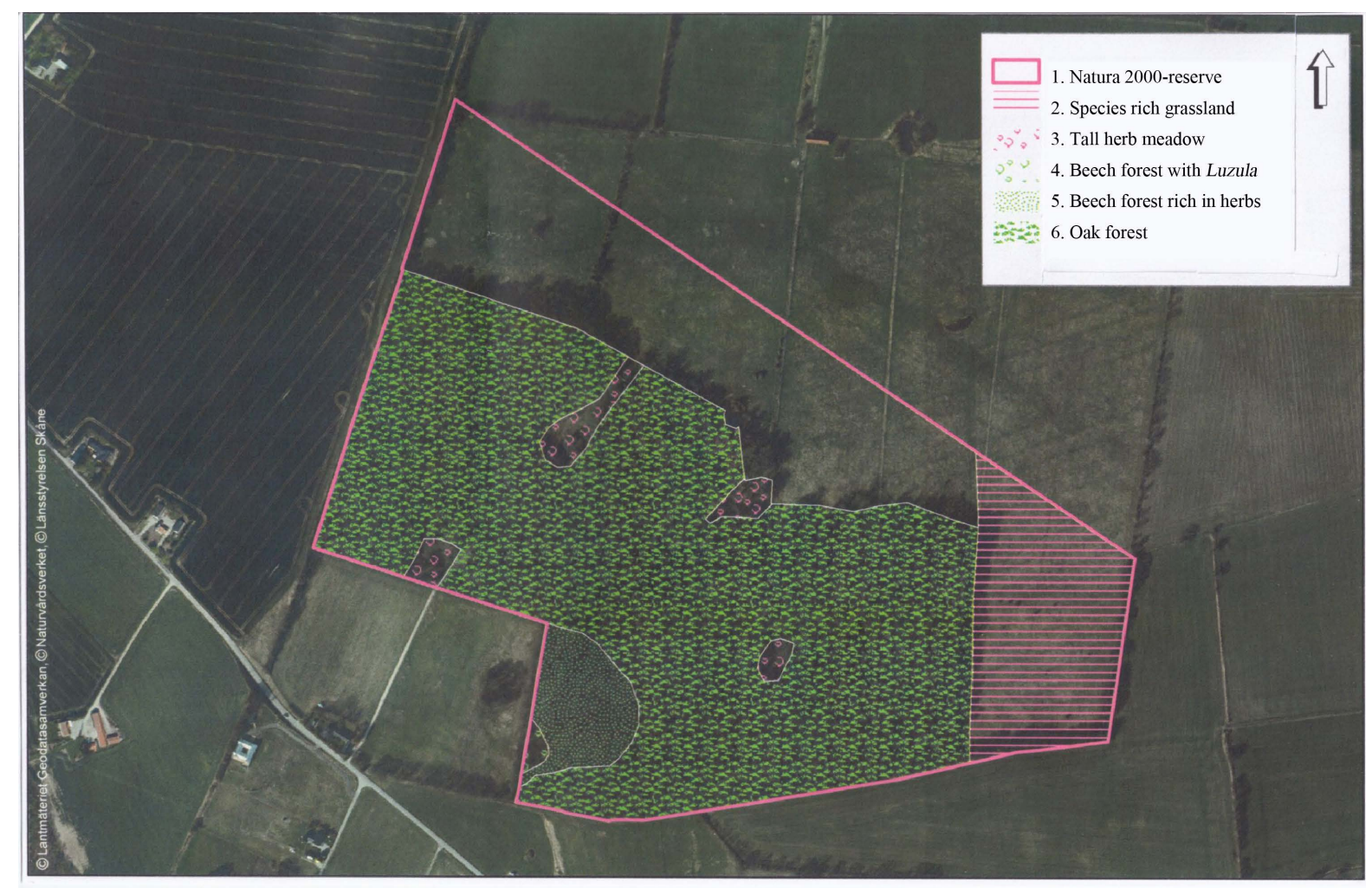

Figure 1. Aerial photo of the Linnebjer nature reserve with the Special area and expended reservation also including open areas of grassland, which altogether forms the new reservation within Natura 2000. The Special area is seen as an opening in the northern part of the forest. Legend: 1. Linnebjer Natura 2000 (limited by red line); 2. Species-rich dry-fresh grassland (red hatched); 3. Tall herb meadow (red circles); 4. Beech forest with Luzula (green circles) beech forest with Oxalis (dots); 6. Oak forest (green canopy). Approved for distribution by Länsstyrelsen, Skåne. 


\section{Aims}

The aims of this paper are:

- $\quad$ To describe the increased vegetation changes and its causes.

- To analyse the possible effects of the increased/decreased deposition of sulphur and nitrogen with respect to soil acidification and effects on nutrient availability on plant growth.

- $\quad$ To analyse the present tree biomass and productivity.

- $\quad$ To analyse changes in carbon, nitrogen and nutrients in the soil.

\section{Methods}

\subsection{Tree Studies}

The methods applied for the studies of trees follow [2] [3]. Measurements were done inside $40 \times 40 \mathrm{~m}$ blocks of the diameter at breast height (DBH, cm) and the total tree height (m).

\subsection{Soil Sampling and Analyses}

Soil sampling was performed at three of the earlier studied sites. Similar sampling procedure and soil treatment was used as is described in [2]. However, due to a high water table the depth of the profiles in the Filipendula meadow and the Carex fens were limited to $30 \mathrm{~cm}$. Double samples were taken at each horizon in steel cylinders for volumetric measurements. Chemical analyses were also performed exactly as described in [2]. The difference was a change in atomic absorption spectrophotometer. Thus the following variables were determined: Reduced dry bulk density, water content, loss on ignition, total $\mathrm{C}$ and $\mathrm{N}$, pH in water and $\mathrm{KCl}$ extracts, exchangeable ions of $\mathrm{Na}, \mathrm{K}, \mathrm{Ca}, \mathrm{Mg}, \mathrm{Mn}, \mathrm{Fe}$ and $\mathrm{H}$ in $1 \mathrm{M}$ AmAc. From the analyses were calculated the percentage of exchangeable metallic cations and base saturation.

\section{Results}

\subsection{Changes of Forest Vegetation}

No specific investigations have been made for analysing the forest ground vegetation changes. The forest tree vegetation has been considered to be in a kind of "steady state". During the last 20 years it was, however, obvious that especially mature oaks were hit by “oak disease”. The vitality of many trees decreased, and many trees appear today as half-dead or dead [5]. The direct reasons were probably climatic extremes (drought periods and bare ground frost) in combination with attacks of pathogens (mostly parasitic fungi on the root system) during the 1990s. Indirectly the deposition and the accumulation of nitrogen in the ecosystem can be the reason.

The dieback was apparent in a specific study of the tree biomass and production of the forest (Table 1), where earlier investigated squares/I-III) 1967 were remeasured 2015. By using the information from the previous investigation [3] it was possible to analyse tree biomass and growth after 50 years — see 6.2.

The latest intervention by Man was the establishment of paths in the forest, which required that some oak trees were taken away. Further, the opening of the meadow of the Special area also required felling of some trees.

\subsection{Tree Biomass and Production}

The observed changes in the tree layer raised a question if the tree biomass and production had changed. By assuming that the allometric regressions for these properties of the forest still were valid a comparison between values from 1967 and 2015 could be done. A revision of the earlier measured areas [3] was performedand vitality, tree diameter and height were observed and measured. The results of the new estimates are given in Table 2. There is an obvious decrease in tree biomass and production compared to the situation 50 years ago.

\subsection{Deposition of Sulphur and Nitrogen}

Deposition of air pollutants as sulphur and nitrogen were measured in Linnebjer 1966 and 1967 in the open field and in the oak forest. Very high values of sulphur in forest throughfall were measured, $34 \mathrm{~kg} \cdot \mathrm{ha}^{-1} .22 \mathrm{~kg} \cdot \mathrm{ha}^{-1} \mathrm{of}$ nitrogen was measured in the forest as well. Unfortunately no on-site measurements are available today (Table 3). 
Table 1. Linnebjer, Sweden. Visual observation of tree vitality of mature oaks (Quercus robur) in July 2015. The trees have been graded: healthy — fully leaved; half healthy— $50 \%$ leaves; dead — no leaves; stump. Observations were made in the same 40 $\times 40 \mathrm{~m}$ plots as those which were used for the original estimation of above-ground tree biomass and production [3].

\begin{tabular}{cccccc}
\hline & Healthy & Half healthy & Dead & Stumps & Total \\
\hline Block I & 9 & 2 & 2 & 5 & 18 \\
Block II & 7 & 0 & 7 & 0 & 14 \\
Block III & 7 & 2 & 2 & 0 & 11 \\
Sum 0.48 ha & 23 & 4 & 11 & 5 & 43 \\
Trees ha $^{-1}$ & 48 & 8 & 23 & 10 & 89 \\
\hline
\end{tabular}

Table 2. Linnebjer, Sweden. Estimation of tree biomass and production from $40 \times 40$ m plots—a comparison 1967 and 2015 . Data from sample plots I-III has been transformed to ton ha $^{-1}$.

\begin{tabular}{|c|c|c|c|c|c|}
\hline \multirow{3}{*}{ Species } & \multicolumn{5}{|c|}{ Above-ground biomass } \\
\hline & \multicolumn{3}{|c|}{ Sample area no and area in ha } & \multirow{2}{*}{$\begin{array}{c}\text { Total } 0.48 \\
\text { Ton }\end{array}$} & \multirow{2}{*}{$\begin{array}{c}\text { Total/ha } \\
\text { Ton } \cdot h^{-1}{ }^{-1}\end{array}$} \\
\hline & I (0.16 ha) & II (0.16 ha) & III (0.16 ha) & & \\
\hline Quercus robur & $27.0 / 22.3$ & $30.2 / 15.0$ & $17.4 / 21.0$ & $74.6 / 58.3$ & 155.3/121.5 \\
\hline Corylus avellana & $3.0 / 1.3$ & $2.4 / 2.1$ & 2.0/1.17 & $8.4 / 4.9$ & $17.4 / 10.1$ \\
\hline Other species & $2.1 / 0.3$ & $3.1 / 0.3$ & $8.5 / 10.6$ & $137 / 10.1$ & $28.5 / 23.2$ \\
\hline Total above ground & $32.1 / 23.8$ & $36.7 / 17.7$ & $27.9 / 32.8$ & $96.7 / 73.3$ & 201.2/154.8 \\
\hline Dead trees (oak) & $-/ 4.12$ & $-/ 11.03$ & $-/ 4.45$ & $-/ 19.6$ & $-/ 40.8$ \\
\hline \multirow{3}{*}{ Species } & \multicolumn{5}{|c|}{ Above-ground yearly production } \\
\hline & \multicolumn{3}{|c|}{ Sample area no and area in ha } & Total 0.48 & Total/ha \\
\hline & I (0.16 ha) & II (0.16 ha) & III (0.16 ha) & Ton & Ton'ha ${ }^{-1}$ \\
\hline Quercus robur & $1.06 / 0.84$ & $1.25 / 056$ & $0.69 / 0.76$ & $3.00 / 2.16$ & $6.25 / 4.50$ \\
\hline Corylus avellana & $0.45 / 0.22$ & $0.64 / 0.39$ & $0.36 / 0.18$ & $1.45 / 0.80$ & $3.02 / 1.64$ \\
\hline Other species & $0.19 / 0.05$ & $0.27 / 0.03$ & $0.54 / 0.63$ & $1.00 / 0.71$ & 2.08/1.48 \\
\hline Total above ground & $1.70 / 1.11$ & $2.16 / 1.00$ & $1.59 / 1.57$ & $5.45 / 3.66$ & $11.35 / 7.63$ \\
\hline Dead trees (oak) & $-/ 0.17$ & $-/ 0.44$ & $-/ 0.14$ & $-/ 0.75$ & $-/ 160$ \\
\hline
\end{tabular}

Table 3. Sulphur and nitrogen deposition to open field and forest-a comparison between S Sweden and Jutland, Denmark showing changes over 50 years in $\mathrm{kg} \cdot \mathrm{ha}^{-1}$. Italics: best guess values.

\begin{tabular}{|c|c|c|c|c|c|}
\hline & Ecosystem & Time & $\mathrm{SO}_{4}-\mathrm{S}$ & $\mathbf{N}_{\text {tot }}$ & Reference \\
\hline \multirow[t]{3}{*}{ Linnebjer, S } & Open field & 1967 & 11.0 & 9.3 & \multirow{3}{*}{$\begin{array}{l}\text { [4]. } \\
\text {-“- } \\
\text {-“- }\end{array}$} \\
\hline & Quercus & 1967 & 34.4 & 22.4 & \\
\hline & Quercus & 2013 & $4-6$ & 12.0 & \\
\hline Baldringe, S & Fagus & 2013 & 3 & 9 & [6]. \\
\hline \multirow[t]{2}{*}{ Skovbjer, DK } & Open field & $1997-2000$ & 7.8 & 12.9 & \multirow{2}{*}{$\begin{array}{l}{[7] .} \\
-“-\end{array}$} \\
\hline & Quercus/Fagus & 1977-2000 & 11.5 & 20.2 & \\
\hline
\end{tabular}

A comparison with other measurements must be done. Values from Baldringe, not so far from Linnebjer, indicate a substantial decrease of sulphur. For nitrogen it is more difficult. A high open field value is assumed, but the throughfall is unsure. The Danish values can be used as a support. 


\section{4. pH, Exchangeable Cations and Base Saturation}

$\mathrm{pH}_{\mathrm{H}_{2} \mathrm{O}}$ in the Oxalis acetosella forest indicated a slight decrease in the upper $30 \mathrm{~cm}$, but an opposite trend at 30 $40 \mathrm{~cm}$ depth, where $\mathrm{pH}$ increased from 4.4 to 4.8 (Table 4). In the Filipendula meadow and the Carex fens $\mathrm{pH}_{\mathrm{H} 2 \mathrm{O}}$ also dropped slightly in the upper horizons, but indicated an increase at $20-30 \mathrm{~cm}$ depth in the Carex caespitosa fen. $\mathrm{pH}_{\mathrm{KCl}}$ indicated similar results. Concerning cations a clear difference was noted between 1-valence and 2-valence cations. 1-valence cations are more easily movable, and especially $\mathrm{K}$ is also taken up in high proportions by the plants. These ions can be expected to vary much more by deposition and water movements and they were lower in the forest and the Filipendula meadow, but had increased in the Carex fens. Ca and $\mathrm{Mg}$ on the other hand are much more bound to the colloids, and indicated a strongly increased accumulation in all the ecosystems, and especially in the meadows. The solubility of $\mathrm{Mn}$ is depending on $\mathrm{pH}$ and increased probably due to the slightly decreased $\mathrm{pH}$ (Table 4).

\subsection{Carbon and Nitrogen in the Soil}

Total carbon (C) and nitrogen $(\mathrm{N})$ of the soil profiles and the estimated $\mathrm{C} / \mathrm{N}$-ratios are given in Table 5. A comparison with results in [2] indicated a dramatic increase in carbon content of the four investigated ecosystems. At $0-10 \mathrm{~cm}$ depth the Oxalis acetosella forest plot had a mean value of $35 \mathrm{~g} \cdot \mathrm{dm}^{-3} 1966$, but 2013 was raised to $56 \mathrm{~g} \cdot \mathrm{dm}^{-3}$. The wet meadow with Filipendula ulmaria had a mean value of $40 \mathrm{~g} \cdot \mathrm{dm}^{-3}$, and increased to 106 $\mathrm{g} \cdot \mathrm{dm}^{-3}$. Even more drastic increase was in the Carex flacca fen, increasing from about $44 \mathrm{~g} \cdot \mathrm{dm}^{-3}$ to $138 \mathrm{~g} \cdot \mathrm{dm}^{-3}$, and the Carex caespitosa fen increasing from about $50 \mathrm{~g} \cdot \mathrm{dm}^{-3}$ to $162 \mathrm{~g} \cdot \mathrm{dm}^{-3}$.

Table 4. Linnebjer, S. Sweden. Effects of vertical and horizontal water flow on soil chemistry, especially acidification and some exchangeable cations. A comparison 1966 and 2015. Element unit: $\mathrm{mmol} \cdot \mathrm{dm}^{-3}$.

\begin{tabular}{|c|c|c|c|c|c|c|c|c|c|}
\hline \multicolumn{10}{|c|}{ Vertical flow 1966/2013 } \\
\hline $\begin{array}{l}\text { Ecosystem and } \\
\text { depth }\end{array}$ & $\mathbf{p H}$ & pH & $\begin{array}{c}\text { Base } \\
\text { sat. }\end{array}$ & $\mathrm{Na}$ & $\mathbf{K}$ & Ca & Mg & Mn & $\mathbf{H}$ \\
\hline & $\mathbf{H}_{2} \mathbf{O}$ & KCl & $\%$ & $\underset{\mathrm{dm}^{-3}}{\mathrm{mmol}}$ & $\underset{\mathbf{d m}^{-3}}{\mathbf{m m o l}}$ & $\underset{\mathrm{dm}^{-3}}{\mathrm{mmol}}$ & $\underset{\mathbf{d m}^{-3}}{\mathbf{m m o l}}$ & $\underset{\mathrm{dm}^{-3}}{\mathrm{mmol}}$ & $\underset{\mathrm{dm}^{-3}}{\mathrm{mmol}}$ \\
\hline \multicolumn{10}{|l|}{$\begin{array}{c}\text { Oxalis acetosella } \\
\text { forest }\end{array}$} \\
\hline $0-10 \mathrm{~cm}$ & $4.6 / 4.2$ & $3.5 / 34$ & $17 / 20$ & $0.88 / 0.71$ & 2.08/1.66 & 4.8/13.5 & $2.1 / 6.8$ & $0.32 / 0.83$ & $86 / 86$ \\
\hline $10-20 \mathrm{~cm}$ & $4.3 / 4.3$ & $3.5 / 3.4$ & $11 / 22$ & $0.97 / 1.11$ & $1.44 / 0.69$ & $2.8 / 12.8$ & $2.1 / 11.2$ & $0.07 / 0.22$ & $93 / 86$ \\
\hline $20-30 \mathrm{~cm}$ & $4.7 / 4.6$ & $3.7 / 3.6$ & $11 / 28$ & $1.18 / 1.01$ & $1.47 / 0.57$ & 2.8/13.3 & 2.5/11.9 & $0.05 / 0.10$ & $105 / 67$ \\
\hline $30-40 \mathrm{~cm}$ & $4.4 / 4.8$ & $3.4 / 3.7$ & $13 / 32$ & $1.85 / 1.03$ & $2.04 / 0.55$ & $2.9 / 14.5$ & $3.2 / 14.3$ & $0.05 / 0.05$ & $107 / 49$ \\
\hline \multicolumn{10}{|c|}{ Horizontal flow 1966/2013 } \\
\hline \multicolumn{10}{|l|}{$\begin{array}{c}\text { Filipendula } \\
\text { meadow }\end{array}$} \\
\hline $0-10 \mathrm{~cm}$ & $6.5 / 6.3$ & $6.1 / 5.5$ & $90 / 90$ & $1.07 / 0.58$ & $2.48 / 1.49$ & $37 / 213$ & $11 / 74$ & $0.01 / 0.53$ & $22 / 30$ \\
\hline $10-20 \mathrm{~cm}$ & $6.3 / 6.5$ & $5.6 / 5.6$ & $87 / 91$ & $2.15 / 1.00$ & $3.73 / 1.37$ & $59 / 172$ & $19 / 66$ & $0.01 / 0.12$ & $27 / 23$ \\
\hline $20-30 \mathrm{~cm}$ & $7.0 / 6.8$ & $6.4 / 5.3$ & $87 / 89$ & $2.74 / 1.52$ & $4.12 / 3.33$ & $66 / 190$ & $26 / 85$ & $0.03 / 0.05$ & $28 / 36$ \\
\hline \multicolumn{10}{|l|}{ Carex flacca fen } \\
\hline $0-10 \mathrm{~cm}$ & $7.1 / 6.2$ & $6.4 / 5.6$ & $92 / 90$ & $1.21 / 4.46$ & $0.79 / 1.84$ & $36 / 248$ & $10 / 80$ & $0.03 / 0.04$ & 7/36 \\
\hline $10-20 \mathrm{~cm}$ & $7.3 / 6.1$ & $6.2 / 5.0$ & $92 / 87$ & $2.11 / 5.48$ & $0.74 / 1.14$ & 13 & $18 / 56$ & $0.02 / 0.02$ & 23/31 \\
\hline $20-30 \mathrm{~cm}$ & $7.0 / 6.8$ & $6.4 / 5.4$ & $92 / 90$ & $3 / 7.18$ & 0.99/1.01 & $58 / 132$ & $20 / 61$ & $0.01 / 0.00$ & $20 / 22$ \\
\hline \multicolumn{10}{|l|}{$\begin{array}{l}\text { Carex caespitosa } \\
\text { fen }\end{array}$} \\
\hline $0-10 \mathrm{~cm}$ & 6.0/6.6 & $5.5 / 5.9$ & $88 / 91$ & $1.02 / 1.24$ & $0.54 / 1.76$ & $29 / 270$ & 8/106 & $0.01 / 0.00$ & $14 / 28$ \\
\hline $10-20 \mathrm{~cm}$ & $7.3 / 6.4$ & $6.2 / 5.5$ & $82 / 90$ & $1.84 / 2.08$ & $0.43 / 0.89$ & $45 / 151$ & $16 / 70$ & $0.03 / 0.00$ & $27 / 26$ \\
\hline $20-30 \mathrm{~cm}$ & $6.7 / 7.0$ & $5.8 / 5.8$ & $89 / 93$ & $2.67 / 2.12$ & $0.68 / 0.82$ & $56 / 143$ & $24 / 79$ & $0.04 / 0.00$ & $30 / 16$ \\
\hline
\end{tabular}


Table 5. Linnebjer, S sweden. estimated total amounts of carbon $(\mathrm{C})$ and nitrogen $(\mathrm{N})$ as well as $\mathrm{C} / \mathrm{N}$-ratios in the soils of the four investigated ecosystems—a comparison 1966 with 2013.

\begin{tabular}{|c|c|c|c|}
\hline \multirow{3}{*}{ Ecosystem and depth } & C-tot. & N-tot. & $\mathbf{C} / \mathbf{N}$ \\
\hline & $1966 / 2013$ & $1966 / 2013$ & $1966 / 2013$ \\
\hline & $\mathbf{g} \cdot \mathbf{d m}^{-3}$ & $\mathbf{g} \cdot \mathbf{d m}^{-3}$ & \\
\hline \multicolumn{4}{|l|}{ Oxalis acetosella forest } \\
\hline $0-10 \mathrm{~cm}$ & $35 / 56$ & $3.4 / 5.3$ & $10.3 / 10.7$ \\
\hline $10-20 \mathrm{~cm}$ & $30 / 40$ & $2.9 / 4.1$ & $10.5 / 9.9$ \\
\hline $20-30 \mathrm{~cm}$ & $16 / 27$ & $2.0 / 2.9$ & 8.0/9.3 \\
\hline $30-40 \mathrm{~cm}$ & $10 / 17$ & $1.6 / 2.0$ & $7.5 / 8.5$ \\
\hline ton $\cdot h^{-1}$ & $92 / 140$ & $9.9 / 14.2$ & $9.3 / 9.9$ \\
\hline Increase (\%) & 52 & 43 & \\
\hline \multicolumn{4}{|l|}{ Filipendula ulmaria } \\
\hline $0-10 \mathrm{~cm}$ & $40 / 106$ & $2.6 / 10.1$ & 11.6/10.6 \\
\hline $10-20 \mathrm{~cm}$ & $46 / 78$ & $3.9 / 8.0$ & $11.8 / 9.8$ \\
\hline $20-30 \mathrm{~cm}$ & $25 / 54$ & $4.6 / 6.5$ & $5.4 / 8.3$ \\
\hline ton $\cdot h^{-1}$ & $111 / 238$ & $11.1 / 24.5$ & $10.0 / 9.7$ \\
\hline Increase (\%) & 114 & 121 & \\
\hline \multicolumn{4}{|l|}{ Carex flacca fen } \\
\hline $0-10 \mathrm{~cm}$ & $44 / 138$ & 4.3/13.0 & $10.2 / 10.7$ \\
\hline $10-20 \mathrm{~cm}$ & $52 / 72$ & $5.2 / 7.8$ & $10.0 / 9.2$ \\
\hline $20-30 \mathrm{~cm}$ & $32 / 39$ & $3.5 / 4.7$ & $9.1 / 8.3$ \\
\hline ton $\cdot h a^{-1}$ & $128 / 249$ & $13.0 / 25.5$ & $9.8 / 9.8$ \\
\hline Increase (\%) & 95 & 96 & \\
\hline \multicolumn{4}{|l|}{ Carex caespitosa fen } \\
\hline $0-10 \mathrm{~cm}$ & $50 / 162$ & $4.5 / 14.5$ & 11.1/11.2 \\
\hline $10-20 \mathrm{~cm}$ & $67 / 90$ & $6.5 / 8.8$ & $10.3 / 10.3$ \\
\hline $20-30 \mathrm{~cm}$ & $49 / 49$ & $6.4 / 5.7$ & 7.7/8.6 \\
\hline ton $\cdot h^{-1}$ & 166/301 & $17.4 / 29.0$ & $9.5 / 10.4$ \\
\hline Increase (\%) & 81 & 67 & \\
\hline
\end{tabular}

The total amount of $\mathrm{C}$ down to $40 \mathrm{~cm}$ in the Oxalis acetosella forest was 1966 estimated to 92 ton/ha ${ }^{-1}$, but 2013 it had increased to $140 \mathrm{ton} \cdot \mathrm{ha}^{-1}$. Down to $30 \mathrm{~cm}$ depth the Filipendula meadow increased from 111 to 238 ton ha $^{-1}$, the Carex flacca fen from 128 to 249 ton $\cdot \mathrm{ha}^{-1}$ and the Carex caespitosa fen from 166 to 301 ton ha $^{-1}$ (Table 5).

Concerning $(\mathrm{N})$ the mean content in $0-10 \mathrm{~cm}$ of the Oxalis-forest was $3.4 \mathrm{~g} \cdot \mathrm{dm}^{-3}$ in 1966 , and had increased to $5.3 \mathrm{~g} \cdot \mathrm{dm}^{-3}$ in 2013. In the Filipendula ulmaria meadow the mean content earlier was $2.6 \mathrm{~g} \cdot \mathrm{dm}^{-3}$ and increased to $10.1 \mathrm{~g} \cdot \mathrm{dm}^{-3}$, in the Carex flacca fen the increase was from $4.3 \mathrm{~g} \cdot \mathrm{dm}^{-3}$ to $13.0 \mathrm{~g} \cdot \mathrm{dm}^{-3}$, and in the Carex caespitosa fen the increase was from 4.5 to $14.5 \mathrm{~g} \cdot \mathrm{dm}^{-3}$ in the upper $10 \mathrm{~cm}$. In the whole profile down to $40 \mathrm{or} 30 \mathrm{~cm}$ there were similar increases to be found (Table 5).

The $\mathrm{C} / \mathrm{N}$ ratio is of importance in understanding tendencies of a relative accumulation of organic matter (= increased ratio), or increased decomposition including accumulation of $\mathrm{N}$ (=decreased ratio). In the Oxalis acetosella forest the ratio showed only a slightly increasing change from 10.3 to 10.7 in the top soil layer, and in the whole profile there was similarly a slight increase of the ratio from 9.3 to 9.9. In the Filipendula ulmaria 
meadow there was instead a tendency to a decrease in the upper $20 \mathrm{~cm}$, but as in the two Carex fens the ratios could be regarded principally unchanged, in spite of the very strong accumulation of both $\mathrm{C}$ and $\mathrm{N}$.

\section{Discussion}

The most evident and visible change in the forest is a decrease in the vitality of the oaks. They were hit by "oak disease" during the 1990s [8]-[10] leading to a decrease in tree biomass, production and also litter fall, and a great increase of dead wood, mostly standing dead. The reasons behind seem to be multifactorial, with climatic stress factors like drought and frost followed by pathogen on the root systems as primary agents. [11] shows the lately spread diseases of Phytophtora species and how forests, semi-natural and horticultural ecosystems are at risk. The continuous accumulation of nitrogen, causing imbalances in nutritional conditions should not be forgotten [11]-[14] as imbalances to nitrogen and relative deficiency of micronutrients like boron, copper and zinkstrongly weaken the resistance to fungi pathogenes [15]. A dieback of $30 \%-40 \%$ of trees especially in one plot obviously reduced the living biomass and the today production of the forest. But the forest ecosystem might have been affected in many other ways that has not been followed. In fact ground vegetation increased due to more light, which resulted in larger herbs among the trees. This in turn might have contributed to a stronger accumulation of fallen leaves during autumn, and subsequently an increase in soil organic matter (cf. below).

In the soils, it seems obvious that a decrease in the deposition of sulphur (primarily sulphuric acid) has resulted in a change of soil acidification [16] and leaching of elements. The highest peak in deposition of sulphur in Sweden was during 1970-1990 [17] [18] and during that period probably a lot of Ca and Mg was transported by horizontal water movements from the above forest soils to the lower situated meadow and the Carex fens. During the last 20 years, however, sulphur deposition has decreased to levels comparable with the situation around 1950 [18] and this is obviously reflected in increased accumulation of weathered Ca and $\mathrm{Mg}$ in the forest soil. This is one explanation to the outstanding changes in exchangeable amounts of $\mathrm{Ca}$ and $\mathrm{Mg}$. Also $\mathrm{Mn}$, more easily dissolved at decreasing $\mathrm{pH}$, shows this tendency. Increased amounts of organic matter (cf. below) should have contributed to the formation of organic colloids and thus the ability to retain these increasing amounts of ions.

As mentioned above, the continued deposition of nitrogen is very important, as $\mathrm{N}$ is usually the limiting element for plant growth. Only minor reductions in SW Sweden are noticed since the 1960s, but there has been a peak during the 1980s. As observed in most areas, the leaching of nitrate from soils is very small, which means that most deposited $\mathrm{N}$ is accumulated in the forests [18] [19]. All over Europe an increase of more than 50\% in forest growth is reported from 1950 to 1995 [20] [21] and the most obvious reason is N deposition. Increased $\mathrm{CO}_{2}$-concentration, increased annual temperature and possible increased rainfall have also all contributed to increased vegetation growth. In Linnebjer this increased growth resulted in oak dieback, a kind of nature's counteraction, but it has probably also contributed to accumulation of $\mathrm{C}$ and $\mathrm{N}$ in the soils.

Increased amounts of $\mathrm{C}$ and $\mathrm{N}$ in the forest soil and principally a doubling of the $\mathrm{C}$ and $\mathrm{N}$ amounts in the wet areas are of interest from many points of view. Both in the forest and especially in the meadow and the wet fens there was a strong accumulation of organic matter, with C and N increasing almost similarly (52\% - 114\% and $43 \%-121 \%$, respectively), though with a tendency towards slightly more $\mathrm{C}$ than $\mathrm{N}$ in most ecosystems, except in the Filipendula meadow that had a stronger $\mathrm{N}$ accumulation in the upper soil layers. As mentioned above the deposition of $\mathrm{N}$ during the last 50 years has varied, but is today relatively similar to the situation in 1960s. The amount in open field at that time was $10-12 \mathrm{~kg} \cdot \mathrm{ha} \cdot \mathrm{yr}^{-1}$, and similar amount is measured today. However, there were higher amounts during the 1970 s and up to 1990 [18].

High $\mathrm{N}$ deposition, increased $\mathrm{CO}_{2}$-concentration and the accompanying temperature increase have caused a much longer vegetation period. Since 1960s the vegetation period has increased by almost 2 weeks in Southern Sweden [22]. These factors should all contribute to more vegetation growth and increased organic matter accumulation in soils. Factors counteracting $\mathrm{C}$ and $\mathrm{N}$ accumulation in the soil should be increased decomposition due to increased temperature, and harvest of biomass. In both the Filipendula meadow and the Carex fens there is since 35 years an annual cutting of the aboveground biomass once in August, but the production of grasses and herbs continue to grow until November. In the forest there has been an obvious dieback, but still it can be expected that the total production of leaves might have increased, as both ground vegetation and hazel shrubs (Corylus avellana) have increased very much. Leaves are spread by wind also to the open field with the meadow and the fens, and thus contribute to organic matter accumulation here. This is most likely very important, as big 
deciduous trees surround the relatively small open field, but we have no data on this.

Increased amount of organic matter naturally causes a decrease of $\mathrm{pH}$ in both water and $\mathrm{KCl}$-extracts. This is seen in the forest, and even more in the open field sites. However, at $30-40 \mathrm{~cm}$ in the forest there was an opposite trend. The explanation for this might be the strongly reduced deposition of sulphuric acid, as this earlier had a strong impact also on deeper soil layers [6] and since this impact decreased the continuous weathering has contributed to more basic cations and slightly raised $\mathrm{pH}$.

Finally should be added that the increased accumulation of organic matter is also of interest from a climate change point of view. It seems obvious that especially wet areas have a great capacity to accumulate $\mathrm{C}$, and thus to some extent to counteract an increasing $\mathrm{CO}_{2}$-level. This is opposite to the normal findings that climate change will increase decomposition and have appositive feedback on $\mathrm{CO}_{2}$ and global warming.

\section{Acknowledgements}

Several people have during this 50 years period been involved in the investigations. During the recent reanalyses I, the principle author, have been assisted by my friend and colleague Prof. em. Bengt Nihlgård. Anders Jonshagen has assisted us at soil sampling and tree measurements in the field. In the laboratory Kurt Olsson, Maj-Lis Gernersson and Sofia Mebrahtu Wisén have done the analyses. Maj-Lis also did some analyses almost 40 years ago. Bengt has been in charge of the analyses. He is also co-author to this paper. I thank him for a never failing support over all the years.

Financial support has been received from C F Lundström Foundation, Stockholm with 110,000 SEK, used for field work and chemical analyses. Further the Extensus foundation, Uppsala has supported the field and laboratory analyses of tree biomass and growth in Linnebjer and Hestehave, Denmark with 32,950 SEK.

I also acknowledge the support from my wife Pirjo with computer technics in finalising the manuscript. The same holds for her constant encouragement.

\section{References}

[1] Andersson, F. (1970) An Ecosystem Approach to Vegetation, Environment and Organic Matter of a Mixed Woodland and Meadow Area. Thesis, Lund University, Lund.

[2] Andersson, F. (1970) Ecological Studies in a Scanian Woodland and Meadow Area, Southern Sweden. II. Vegetational and Environmental Structure. Opera Botanica, Lund, 190 p.

[3] Andersson, F. (1970) Ecological Studies in a Scanian Woodland and Meadow Area, Southern Sweden. II. Plant Biomass, Primary Production and Turnover of Organic Matter. Botaniska Notiser, 123, 8-51.

[4] Andersson, F.O. (2014) Plant Biomass, Primary Production and Mineral Cycling of a Mixed Oak Forest in Linnebjer, Sweden. Open Journal of Forestry, 4, 570-580.

[5] Ågren, G.I. and Andersson, F.O. (2012) Terrestrial Ecosystem Science-Principles and Applications. Cambridge University Press, Cambridge, 230.

[6] Pihl Karlsson, G., Akselsson, G., Hellsten, S., Kronnäs, V. and Karlsson, P.E. (2015) The State of the Forest Environment in Scania. Report C 112, The Swedish Environment Institute, Gothenburg, 38 p. (In Swedish)

[7] Andersson, F.O. (2015) Matter Decomposition Hestehave, Jutland, Denmark, in a 50 Year Perspective. Open Journal of Forestry, 5, 296-312. http://dx.doi.org/10.4236/ojf.2015.53026

[8] Attocchi, G. (2015) Silviculture of Oak for High-Quality Wood Production. Effects of Thinning on Crown Size, Volume Growth and Stem Quality in Even-Aged Stands of Pedunculate Oak (Quercus robur L.) in Northern Europe. Acta Universitatis Agriculturae Suecica, Doctoral Thesis, 39.

[9] Datnoff, L.E., Elmer, W.H. and Huber, D.M. (2007) Mineral Nutrition and Plant Disease. The Amercan Phytopathological Society, USA.

[10] Drobychev, I., Linderson, H. and Sonesson, K. (2007) Temporal Mortality of Pedunculate Oak in Sweden. A Literature Review, Report VPE, No. 7, SLU, Uppsala.

[11] Jung, et al. (2015) Widespread Phytophthora Infestations in European Nurseries Put Forests, Semi-Natural and Horticultural Ecosystems at Risk. For. Pathology.

[12] Jönsson, U. and Rosengren, U. (2005) Can Phytophthora quercina Have a Negative Impact on Mature Pedunculate Oaks under Field Conditions? Annals of Forest Science, 63, 661-672. http://dx.doi.org/10.1051/forest:2006047

[13] Kirschbaum, M.U.F. (1995) The Temperature Dependence of Soil Organic Matter Decomposition and the Effect of Global Warming on Soil Organic C Storage. Soil Biology \& Biochemistry, 27, 753-760. 
http://dx.doi.org/10.1016/0038-0717(94)00242-S

[14] Nihlgård, B. (1972) Plant Biomass, Primary Production and Distribution of Chemical Elements in a Beech and a Planted Spruce Forest in South Sweden. Oikos, 23, 68-91. http://dx.doi.org/10.2307/3543928

[15] Nihlgård, B. (1977) Plant Biomass, Primary Production and Bioelements of Three Mature Beech Forests in South Sweden. Oikos, 28, 95-104. http://dx.doi.org/10.2307/3543328

[16] Helyar, K.R. and Porter, W.M. (1989) Soil Acidification, Its Measurements and the Processes Involved. In: Robson, .A.D., Ed., Soil Acidity and Plant Growth, Academic Press, Sydney, 61-101. http://dx.doi.org/10.1016/b978-0-12-590655-5.50007-4

[17] Nihlgård, B. (1985) The Ammonium Hypothesis—An Additional Explanation to the Forest Dieback in Europe. Ambio, 14, 2-8.

[18] Nihlgård, B. (1997) Forest Decline and Environmental Stress. In: Chapman, D., Ed., The Global Environment, VCH, 422-440. http://dx.doi.org/10.1002/9783527619658.ch24

[19] Elfving, B., Tegnhammar, L. and Tveite, B. (1996) Studies in Growth Trends of Forests in Sweden and Norway. In: Spiecker, et al., Eds., Growth Trends in European Forests, Report No. 5, Springer. http://dx.doi.org/10.1007/978-3-642-61178-0_6

[20] Nihlgård, B. (1970) Precipitation, Its Chemical Composition and Effect on Soil Water in a Beech and a Spruce Forest in South Sweden. Oikos, 21, 208-217. http://dx.doi.org/10.2307/3543676

[21] Pihl Karlsson, G., Akselsson, G., Hellsten, S. and Karlsson, P.E. (2011) Reduced European Emissions of S and NEffects on Air Concentrations, Deposition and Soil Water Chemistry in Swedish Forests. Environmental Pollution, 159, 3571-3582. http://dx.doi.org/10.1016/j.envpol.2011.08.007

[22] SMHI (2015) Klimatindikatorer_Vegetationsperiodens Längd. (Climate Indicators_Length of Vegetation Period). Kunskapsbanken. www.smhi.se 